\title{
PENGARUH TAX AMNESTY TERHADAP PROFITABILITAS PERUSAHAAN YANG TERDAFTAR DI BURSA EFEK INDONESIA
}

\author{
HOW TAX AMNESTY IMPACTS THE PROFITABILITY OF INDONESIAN COMPANIES LISTED AT \\ INDONESIA STOCK EXCHANGE
}

\author{
Ali Akil Parlindungan Siregar ${ }^{*}$, , Noer Azam Achsani*), dan Hendro Sasongko ${ }^{* *}$ \\ ${ }^{*}$ Sekolah Bisnis, IPB University \\ Jl Pajajaran Bogor, 16151, Indonesia \\ ${ }^{* *)}$ Fakultas Ekonomi, Universitas Pakuan \\ Jl. Pakuan Kotak Pos 452. Ciheuleut Bogor 16129, Indonesia
}

\begin{abstract}
Tax amnesty policy in Indonesia has an impact on companies listed on the Capital Market. Companies that take advantage of tax amnesty can be identified from the increase in net assets and equity. This increase results in an increase or decrease in profitability and may affect investors' interest in investing. This research aimed to analyze the influence of tax amnesty and internal and external factors on the company's profitability. This study's samples are companies listed on the main board of the Indonesia Stock Exchange between 2013 and 2018. Panel data regression was used in this study to analyze the data. The result showed that tax amnesty had a significant negative effect on profitability. Internal factors that had a significant positive effect on profitability were current ratio and total asset turnover, while debt to equity ratio negatively affected profitability. External factors that had a significant positive effect on profitability were interest rates and rupiah exchange rates. Tax amnesty negatively affected profitability resulting in corporate profits declining dramatically during the tax amnesty program. Based on the results, it could be concluded that several factors could affect profitability, such as tax amnesty policy, internal factors, and external factors of the company.
\end{abstract}

Keywords: external factors, internal factors, panel data regression, profitability, tax amnesty

\begin{abstract}
Abstrak: Kebijakan tax amnesty di Indonesia memiliki dampak pada perusahaan yang tercatat di Pasar Modal. Perusahaan yang memanfaatkan tax amnesty dapat diketahui dari bertambahnya harta bersih dan ekuitas. Pertambahan tersebut dapat mengakibatkan peningkatan atau penurunan profitabilitas dan dapat berpengaruh terhadap minat investor dalam berinvestasi. Penelitian ini bertujuan menganalisis pengaruh tax amnesty, faktor internal dan eksternal terhadap profitabilitas perusahaan. Sampel dari penelitian ini adalah perusahaan yang terdaftar di papan utama Bursa Efek Indonesia dengan periode penelitian 2013-2018. Regresi data panel digunakan dalam penelitian ini untuk menganalisis data. Hasil penelitian menunjukkan tax amnesty berpengaruh negatif signifikan terhadap profitabilitas. Faktor internal yang berpengaruh positif signifikan terhadap profitabilitas adalah current ratio dan total asset turn over, sedangkan debt to equity ratio berpengaruh negatif signifikan terhadap profitabilitas. Faktor eksternal yang berpengaruh positif signifikan terhadap profitabilitas adalah suku bunga dan nilai tukar rupiah. Tax amnesty yang berpengaruh negatif terhadap profitabilitas mengakibatkan keuntungan perusahaan menurun drastis selama program tax amnesty berlangsung. Berdasarkan hasil penelitian dapat disimpulkan bahwa ada berbagai faktor yang dapat mempengaruhi profitabilitas, yaitu kebijakan tax amnesty, faktor internal, dan faktor eksternal dari perusahaan.
\end{abstract}

Kata kunci: faktor eksternal, faktor internal, profitabilitas, regresi data panel, tax amnesty

\footnotetext{
${ }^{1}$ Corresponding author:

Email: akil.regar@gmail.com
} 


\section{PENDAHULUAN}

Tax amnesty merupakan salah satu kebijakan fiskal yang diterapkan dengan cara menghapus pajak yang seharusnya terutang, tidak dikenai sanksi administrasi perpajakan dan sanksi pidana di bidang perpajakan (Saraçoğlu dan Çaşkurlu, 2011). Program tax amnesty di Indonesia diberlakukan pada tanggal 1 Juli 2016 hingga 31 Maret 2017. Setelah program tersebut dilaksakan, terdapat beberapa emiten yang mengikuti program tax amnesty. Hal ini berarti bahwa emiten tersebut tidak mematuhi dan melanggar prinsip Good Corporate Governance (GCG) serta emiten tersebut melakukan tax evasion. Kebijakan tax amnesty di Indonesia memiliki dampak yang berbeda-beda bagi setiap sektor perekonomian termasuk perusahaan (emiten) yang tercatat di Pasar Modal (Bursa Efek Indonesia). Salah satu indikator perusahaan yang memanfaatkan tax amnesty adalah bertambahnya harta bersih dan ekuitas. Selain itu, likuiditas gateway yang meningkat, misalnya perbankan, akan memacu institusi perbankan untuk meningkatkan penyaluran kredit, selain dari investasi langsung melalui transaksi saham di pasar modal. Perubahan aset maupun dukungan instrumen finansial terhadap emiten ini diduga akan dimanfaatkan dengan baik oleh emiten dan berimbas pada peningkatan kinerja keuangan pada laporan keuangan tahunan emiten. Vireyto dan Sulasmiyati (2017) mengatakan bahwa investor sangat memperhatikan tingkat profitabilitas perusahaan yang ditunjukkan melalui pengaruh signifikan pada beberapa indikator keuangan emiten.

Kinerja keuangan dengan indikator profitabilitas juga dipengaruhi oleh faktor-faktor lain seperti faktor internal dan eksternal. Faktor eksternal merupakan faktor yang tidak dapat dikendalikan oleh perusahaan yang biasanya berpengaruh pada skala industri (Allen et al. 2011). Faktor tersebut diantaranya inflasi, tingkat suku bunga, nilai tukar (kurs), dan produk domestik bruto (PDB) (Sahara, 2013; Karim, 2015). Faktor internal yang memengaruhi profitabilitas berhubungan dengan kondisi internal yang masih dapat dikendalikan oleh perusahaan. Faktor internal tersebut dapat dilihat dari berbagai aspek indikator seperti likuiditas, aktivitas (efisiensi), dan solvabilitas (leverage) (De Carvalho et al. 2013; Saleh dan Mohammed, 2018). Metode yang digunakan dalam penelitian ini yaitu regresi data panel yang merujuk pada beberapa penelitian sebelumnya seperti Allen et al. (2011) dan Lee (2014).
Tax amnesty membuat perusahaan yang awalnya mencoba menyembunyikan aset dan kewajiban di dalam laporan keuangannya menjadi jelas (Rinaldi, 2017). Hal ini membuat laporan keuangan menjadi lebih transparan sehingga asymetric information antara perusahaan dengan pihak luar (investor, kreditur, pemerintah) dapat berkurang. Beberapa penelitian sebelumnya menemukan bahwa tax amnesty memiliki dampak yang berbeda-beda bagi perusahaan. Ariani et al. (2018) menjelaskan bahwa tingkat profitabilitas perusahaan meningkat setelah tax amnesty. Sebaliknya, menurut Rinaldi (2017) profitabilitas perusahaan justru menurun setelah tax amnesty. Adanya pengakuan aset dan kewajiban oleh perusahaan setelah mengikuti tax amnesty akan diikuti dengan biaya-biaya yang menyertainya sehingga biaya operasional perusahaan akan semakin besar. Meningkatnya biaya operasional berdampak pada penurunan laba perusahaan.

Faktor internal yang mampu memengaruhi profitabilitas perusahaan antara lain liquidity, leverage, dan efficiency. Current ratio merupakan salah satu rasio pengukuran dari tingkat likuiditas perusahaan. Likuiditas dan profitabilitas dipandang sebagai dua hal yang berlawanan namun keberadaannya tidak dapat dipisahkan. Perusahaan harus mampu menjaga tingkat likuiditas perusahaan dengan memperbesar cadangan kas. Meningkatnya cadangan kas dapat berakibat pada idle cash yang berdampak pada penurunan profitabilitas (Ramadanti dan Meiranto, 2015). Ulzanah dan Murtaqi (2015) juga menjelaskan bahwa ketika perusahaan mengalokasikan dana yang dicadangkan untuk memenuhi likuiditas perusahaan maka perusahaan akan kehilangan kesempatan untuk mendapatkan lebih banyak laba. Menurut Elsiefy (2013) dan Al-Jafari dan Alchami (2014) likuiditas berpengaruh negatif terhadap profitabilitas. Leverage adalah salah satu komponen struktur modal suatu perusahaan. Perusahaan yang menggunakan pinjaman besar menghadapi risiko yang lebih tinggi sementara perusahaan yang menggunakan lebih banyak ekuitas cenderung beroperasi lebih konservatif dengan mengandalkan dana internal (Saleh dan Mohammed, 2018). Hasil penelitian Ulzanah dan Murtaqi (2015) menjelaskan bahwa debt to equity ratio (DER) berpengaruh negatif signifikan terhadap profitabilitas. Perusahaan dengan DER yang lebih tinggi dianggap lebih berisiko karena porsi utang yang digunakan lebih tinggi dari porsi ekuitas. Kondisi tersebut akan menghasilkan beban bunga yang lebih tinggi yang akan menurunkan laba dan membuat tingkat profitabilitas perusahaan menurun. 
Efisiensi perusahaan juga dapat digambarkan dari total asset turnover ratio. Rasio total asset turnover (TATO) digunakan untuk mengukur jumlah penjualan yang diperoleh dari tiap rupiah yang diinvestasikan dalam bentuk aset (Mahaputra, 2012). Rasio ini menggambarkan efisiensi perusahaan dalam mengelola asetnya serta mengukur efektivitas operasi perusahaan (Pervan dan Mlikota, 2013). Perusahaan yang efektif dalam mengelola asetnya mampu menghasilkan total penjualan bersih lebih tinggi. Perputaran aset yang cepat dan diikuti dengan penjualan yang tinggi akan mampu menghasilkan laba (Barus dan Leliani, 2013). TATO yang semakin tinggi berarti perusahaan semakin efisien dan berdampak pada peningkatan profitabilitas. Beberapa faktor eksternal yang dapat memengaruhi profitabilitas yaitu produk domestik bruto, inflasi,tingkat sukubunga, dan kurs. Produk domestikbruto(PDB)yang meningkat menandakan bahwa daya beli masyarakat juga meningkat. Peningkatan daya beli ini berpeluang meningkatkan penjualan perusahaan. Penjualan yang meningkat akan meningkatkan keuntungan perusahaan sehingga menarik perhatian investor untuk berinvestasi. Ketika PDB menurun maka tingkat pengangguran akan meningkat dan investasi rendah sehingga akan menurunkan laba perusahaan (Yuksel dan Zengin, 2017). Untuk itu PDB yang meningkat akan meningkatkan laba perusahaan. Hasil penelitian Sahara (2013) menunjukkan bahwa PDB berpengaruh positif signifikan terhadap profitabilitas. Tingginya tingkat inflasi juga meningkatan biaya perusahaan karena biaya produksi meningkat. Peningkatan biaya produksi yang lebih tinggi daripada peningkatan harga jual akan menurunkan laba perusahaan. Selain itu, inflasi yang meningkat akan menurunkan daya beli masyarakat. Jika daya beli menurun maka penjualan perusahaan akan menurun. Hal ini akan membuat pendapatan perusahaan menurun dan berdampak pada penurunan laba perusahaan. Kalengkongan (2013) berpendapat bahwa inflasi berpengaruh negatif signifikan terhadap profitabilitas.

Perusahaan harus memperhatikan tingkat suku bunga apabila berkeinginan untuk meningkatkan modal dalam bentuk pinjaman. Suku bunga yang rendah menyebabkan biaya peminjaman menjadi lebih rendah dan sebaliknya (Karim, 2015). Kenaikan suku bunga akan meningkatkan beban bunga dan biaya modal bagi perusahaan. Semakin tinggi pinjaman, beban biaya yang harus ditanggung perusahaan akan semakin besar sehingga meningkatnya beban produksi. Hal ini menyebabkan laba perusahaan menurun (Andes et al.
2017). Nilai tukar mata uang (kurs) yang terapresiasi atau terdepresiasi akan memengaruhi perekonomian terutama dalam hal investasi riil. Hal ini berpengaruh terhadap profitabilitas perusahaan. Kewal (2012) menyatakan bahwa perubahan kurs memengaruhi pendapatan dan biaya operasional perusahaan. Kurs yang terapresiasi akan meningkatkan profitabilitas (Zhang dan Ouyang, 2018). Sebaliknya, kurs yang terdepresiasi akan menurunkan profitabilitas (Ulfa et al. 2016).

Hasil penelitian dapat dijadikan sebagai acuan oleh investor atau pelaku pasar modal dalam memprediksi dampak pada emiten dan pasar modal secara agregat apabila kebijakan tax amnesty atau kebijakan fiskal serupa diterapkan di kemudian hari, dan sebagai pijakan bagi pemerintah dalam memprediksi dampak kebijakan apabila melakukan hal serupa di kemudian hari. Untuk mengetahui dampak dari kebijakan tax amnesty akan digunakan metode regrsi data panel. Penggunaan metode tersebut diharapkan akan mampu menggambarkan pengaruh kebijakan tax amnesty terhadap profitabilitas emiten sehingga emiten dapat mempersiapkan strategi apabila kebijakan tersebut diadakan lagi.

Penelitian ini bertujuan mengidentifikasi dan menganalisis pengaruh tax amnesty dan faktor internal maupun eksternal terhadap profitabilitas. Faktor internal yang diduga berpengaruh terhadap profitabilitas adalah likuiditas, efisiensi, dan leverage. Adapun faktor eksternal yang diduga berpengaruh terhadap profitabilitas adalah PDB, inflasi, kurs, dan tingkat suku bunga. Ruang lingkup penelitian ini adalah untuk menganalisis pengaruh tax amnesty terhadap profitabilitas emiten yang terdaftar di papan utama Bursa Efek Indonesia dari tahun 2013 hingga 2018.

\section{METODE PENELITIAN}

Penelitian dilakukan pada bulan April-Juni 2020 yang meliputi studi literatur, pengambilan sampel dan pengolahan data, serta analisis hasil. Pengolahan data dan analisis hasil dilakukan di Sekolah Pasca Sarjana, Institut Pertanian Bogor.

Penelitian ini menggunakan data sekunder yang berasal dari laporan keuangan tahunan pada perusahaan yang tercatat di papan utama Bursa Efek Indonesia dari tahun 2013-2018. Laporan keuangan tersebut diperoleh 
melalui website resmi perusahaan dan Bank Indonesia serta dokumen publikasi resmi yang dimiliki Bursa Efek Indonesia.

Jumlah populasi pada penelitian ini adalah 283 emiten. Teknik pengambilan sampel yang digunakan adalah purposive sampling. Kriteria sampel yang diambil yaitu emiten yang terdaftar pada papan utama Bursa Efek Indonesia dan IPO (Initial Public Offering) sebelum tahun 2015. Selain itu, untuk mengetahui apakah perusahaan mengikuti tax amnesty atau tidak, dapat diketahui dari laporan keuangannya yang mengacu pada PSAK 70. Berdasarkan kriteria tersebut, terdapat 269 emiten yang dapat dijadikan sampel dalam penelitian ini. Pengolahan data dengan metode regresi data panel digunakan sebagai alat analisis untuk menguji faktorfaktor yang memengaruhi profitabilitas.

Data panel digunakan karena pada penelitian ini mengkombinasikan data time series dan cross section (Sumantyo dan Savitri, 2019). Model regresi data panel yang digunakan dalam penelitian ini ada 3 yaitu common effect model (CEM), fixed effect model (FEM), dan random effect model (REM), kemudian dipilih model terbaik. Adapun model dari regresi data panel dalam penelitian ini adalah sebagai berikut:

$$
\begin{aligned}
\mathrm{NPM}_{\mathrm{it}}= & \beta_{0}-\beta_{1} \mathrm{TA}_{\mathrm{it}}-\beta_{2} C R_{\mathrm{it}}-\beta_{3} D E R_{\mathrm{it}}+\beta_{4} T A T O_{\mathrm{it}} \\
& +\beta_{5} P D B_{\mathrm{it}}-\beta_{6} \mathrm{INFLASI}_{\mathrm{it}}-\beta_{7} \mathrm{BUNGA}_{\mathrm{it}}+ \\
& \beta_{8} K U R S_{\mathrm{it}}+e
\end{aligned}
$$

Dimana TAadalah variabel tax amnesty pada perusahaan $i$ dan pada tahun $t$. $\beta_{0}$ adalah konstanta, $\beta_{1-8}$ merupakan koefisien regresi, dan e yaitu error.

\section{Hipotesis}

Net profit margin (NPM) menjadi variabel yang mewakili rasio profitabilitas perusahaan sebagai variabel dependen, sedangkan tax amnesty (TA), faktor internal dan eksternal perusahaan menjadi variabel independen. Variabel NPM dipilih dengan merujuk pada penelitian-penelitian yang menggunakan NPM sebagai indikator profitabilitas, diantaranya Allen et al. (2011) dan Rehman et al. (2014). Selain itu NPM digunakan karena laba bersih merupakan muara dari gross profit margin (GPM), operating profit margin (OPM), dan pretax profit margin (PPM). Penggunaan NPM dikarenakan lebih mendekati untuk memperkirakan pajak terutang atau tidak dibandingkan dengan GPM, OPM, dan PPM. Salah satu manfaat dari tax amnesty adalah naiknya pertumbuhan ekonomi dan pertumbuhan ekonomi kaitannya dengan pertumbuhan produksi barang dan jasa. Untuk itu, NPM lebih cocok digunakan sebagai variabel dependen. Variabel tax amnesty merupakan kebijakan penghapusan pajak kepada wajib pajak yang seharusnya terhutang. Variabel ini menggunakan variabel dummy 0 dan 1 yang menjadi dasar kebijakan tersebut dilaksanakan. Variabel TA bernilai 0 untuk semua perusahaan dari tahun 2013 hingga 2015 dan bernilai 1 untuk semua perusahaan dari tahun 2016 hingga 2018. Faktor internal menggunakan variabel current ratio (CR), total assets turnover ratio (TATO), dan debt to equity ratio (DER). Ketiga variabel internal tersebut sudah cukup mewakili faktor internal karena sudah mewakili tingkat likuiditas (CR), efisiensi (TATO), dan leverage (DER) perusahaan. Tingkat likuiditas perusahaan diperlukan untuk mengukur kemampuan perusahaan dalam membayar kewajiban jangka pendek yang jatuh tempo. Jika perusahaan sudah tidak mampu membayar kewajiban jangka pendeknya maka perusahaan tersebut dapat mengalami krisis keuangan. Efisiensi perusahaan akan menggambarkan kemampuan perusahaan dalam mengelola dan melaksanakan aktivitas sehari-hari baik dalam kegiatan penjualan, pembelian, produksi, dan sebagainya (Harahap, 2011). Leverage perusahaan diperlukan karena variabel ini akan menggambarkan kemampuan perusahaan dalam memenuhi kewajiban keuangannyaapabilaperusahaantersebutdilikuidasikan, baik kewajiban jangka pendek maupun jangka panjang (Munawir, 2004).

Adapun faktor eksternal menggunakan variabel produk domestik bruto (PDB), inflasi (INFLASI), tingkat suku bunga (BUNGA), dan nilai tukar rupiah (KURS). Faktor eksternal merupakan faktor yang tidak dapat dikendalikan oleh perusahaan yang biasanya berpengaruh pada skala industri (Athanasoglou et al. 2008; Allen et al. 2011). Kondisi ini akan memengaruhi operasional perusahaan dalam hal pengambilan kebijakan yang berkaitan dengan kinerja perusahaan. Perlakuan data eksternal yang hanya berbeda kurun waktu maka setiap perusahaan akan memiliki data yang yang sama untuk variabel eksternal per tahunnya. Hipotesis dari penelitian ini adalah sebagai berikut:

$\mathrm{H}_{01}$ : Tax amnesty tidak berpengaruh negatif signifikan terhadap net profit margin.

$\mathrm{H}_{11}$ : Tax amnesty berpengaruh negatif signifikan terhadap net profit margin.

$\mathrm{H}_{02}$ : Currentratio tidak berpengaruh negatifsignifikan terhadap net profit margin. 
$\mathrm{H}_{12}$ : Current ratio berpengaruh negatif signifikan terhadap net profit margin.

$\mathrm{H}_{03}$ : Debt to equity ratio tidak berpengaruh negatif signifikan terhadap net profit margin.

$\mathrm{H}_{13}$ : Debt to equity ratio berpengaruh negatif signifikan terhadap net profit margin.

$\mathrm{H}_{04}$ : Total assets turnover ratio tidak berpengaruh positif signifikan terhadap net profit margin.

$\mathrm{H}_{14}$ : Total assets turnover ratio berpengaruh positif signifikan terhadap net profit margin.

$\mathrm{H}_{05}$ : Produk domestik bruto tidak berpengaruh positif signifikan terhadap net profit margin.

$\mathrm{H}_{15}$ : Produk domestik bruto berpengaruh positif signifikan terhadap net profit margin.

$\mathrm{H}_{06}$ : Inflasi tidak berpengaruh negatif signifikan terhadap net profit margin.

$\mathrm{H}_{16}$ : Inflasi berpengaruh negatif signifikan terhadap net profit margin.

$\mathrm{H}_{07}$ : Tingkat suku bunga tidak berpengaruh negatif signifikan terhadap net profit margin.

$\mathrm{H}_{17}$ : Tingkat suku bunga berpengaruh negatif signifikan terhadap net profit margin.

$\mathrm{H}_{08}$ : Kurs tidak berpengaruh positif signifikan terhadap net profit margin.
$\mathrm{H}_{18}$ : Kurs berpengaruh positif signifikan terhadap net profit margin.

Perusahaan publik seharusnya telah mematuhi prinsip GoodCorporateGovernance(GCG) sepertiketerbukaan (transparency), akuntabilitas (accountability), tanggung jawab (responsibility), independensi (independency), serta kewajaran dan kesetaraan (fairness). Namun pada kenyataannya terdapat perusahaan yang tidak mematuhi prinsip GCG karena ada perusahaan yang melakukan tax evasion. Perusahaan yang melakukan tax evasion terlihat dari keikutsertaan perusahaan publik dalam program tax amnesty. Untuk itu akan diidentifikasi perusahaan yang mengikuti kebijakan tax amnesty kemudian bagaimana kebijakan tersebut akan berdampak pada profitabilitas perusahaan publik. Selain kebijakan tax amnesty, diduga terdapat faktor lain yang akan memengaruhi profitabilitas perusahaan. Faktor lain tersebut antara lain faktor internal dan eksternal perusahaan. Pengujian dengan menggunakan metode regresi data panel diperlukan untuk menjawab hipotesis yang disusun. Kerangka pemikiran pada penelitian ini dapat dilihat pada Gambar 1 .

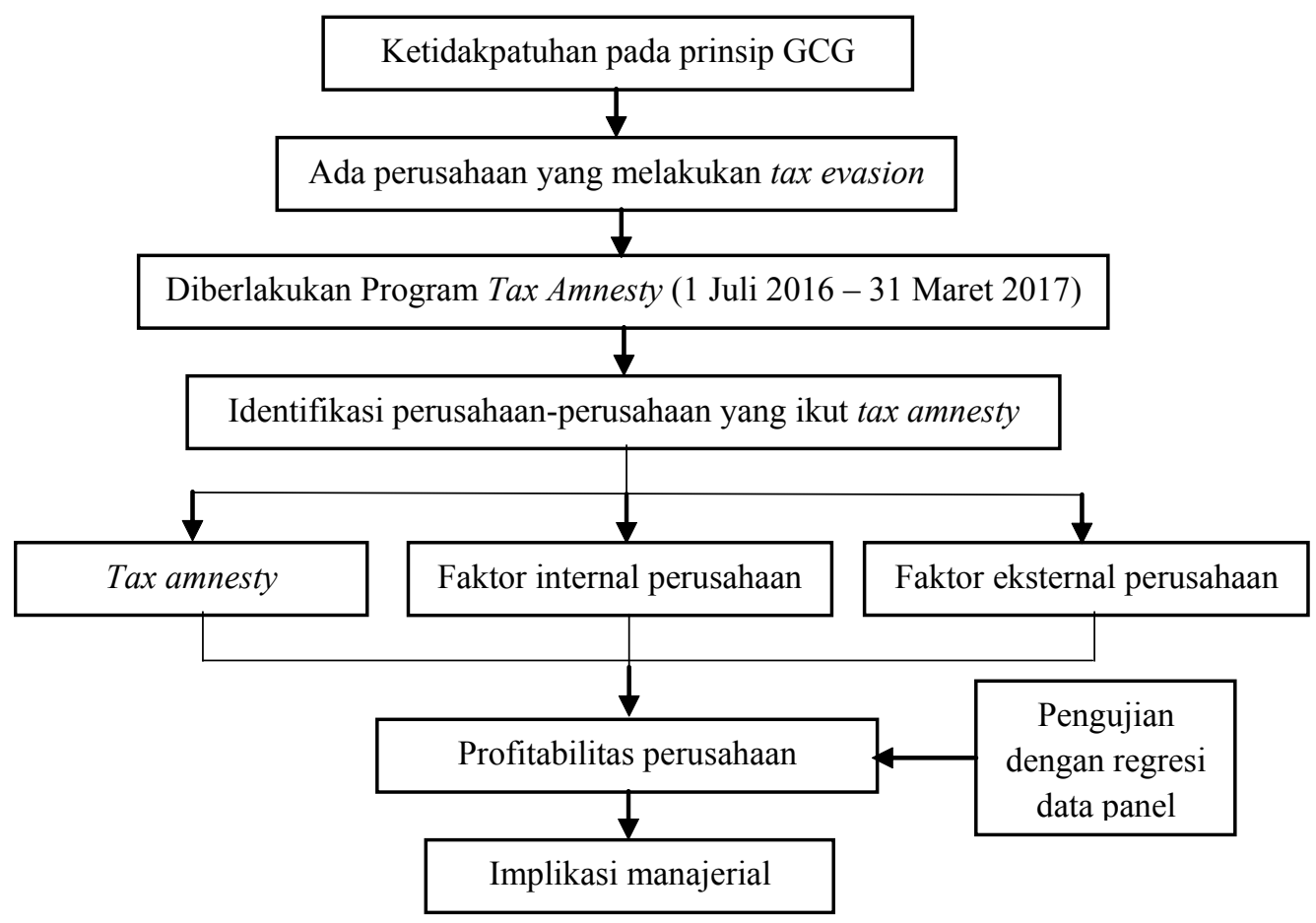

Gambar 1. Kerangka pemikiran penelitian 


\section{HASIL}

\section{Uji Multikolinearitas}

Uji multikolinearitas dilakukan untuk melihat korelasi antar variabel independen. Hasil uji multikolinieritas disajikan pada Tabel 1 dan Tabel 2. Ada kemungkinan interaksi yang terjadi antara variabel internal perusahaan dengan variabel tax amnesty. Namun perusahaan yang mengikuti tax amnesty sedikit, sehingga perusahaan yang mengalami pertambahan aset, hutang, dan ekuitas karena mengikuti tax amnesty juga sedikit. Hasil ini diperkuat dengan hasil pengujian multikolinieritas, dimana variabel internal perusahaan justru memiliki korelasi yang kecil dengan variabel tax amnesty.

Hubungan antar variabel independen dikatakan memiliki korelasi kuat (terdapat multikolinearitas) apabila nilai korelasinya lebih besar dari 0.8. Apabila terdapat korelasi yang kuat antar variabel independen maka salah satu variabel dapat dikeluarkan dari model (Santoso, 2018). Apabila pada model terdapat multikolinieritas dan tidak dikeluarkan dari model maka dapat menyebabkan kesimpulan yang diambil kurang tepat (Ariefianto, 2012). Hasil uji dari variabel yang akan diregresikan dalam penelitian ini menunjukkan adanya multikolinearitas antar beberapa variabel independen yaitu variabel Inflasi, Kurs, PDB, dan TA. Model tidak bisa dijalankan apabila masih terdapat multikolinearitas sehingga ada variabel yang perlu dikeluarkan dari model. Uji multikolinearitas kembali dilakukan setelah variabel Inflasi dan PDB dikeluarkan. Hasil menunjukkan bahwa semua variabel independen memiliki korelasi kurang dari 0.8. Berdasarkan hal tersebut, variabel-variabel yang akan diregresikan sudah tidak ada multikolinearitas.

\section{Pemilihan Model Terbaik}

Terdapat 3 model regresi data panel yang diuji dalam penelitian ini yaitu common effect model (CEM), fixed effect model (FEM), dan random effect model (REM). Uji model tersebut menggunakan uji Chow dan uji Hausman untuk menentukan model terbaik. Hasil uji Chow dan uji Hausman disajikan pada Tabel 3.

Tabel 1. Hasil uji multikolinieritas awal

\begin{tabular}{lcccccccc}
\hline & CR & DER & TATO & INFLASI & BUNGA & KURS & PDB & TA \\
\hline CR & 1,000 & $-0,116$ & 0,020 & $-0,024$ & $-0,024$ & 0,015 & 0,018 & 0,025 \\
DER & $-0,116$ & 1,000 & $-0,075$ & $-0,025$ & 0,005 & 0,012 & 0,013 & 0,027 \\
TATO & 0,020 & $-0,075$ & 1,000 & 0,005 & $-0,024$ & $-0,024$ & $-0,016$ & $-0,001$ \\
INFLASI & $-0,024$ & $-0,025$ & 0,005 & 1,000 & 0,185 & $-0,790$ & $-0,901$ & $-0,986$ \\
BUNGA & $-0,024$ & 0,005 & $-0,024$ & 0,185 & 1,000 & 0,164 & $-0,036$ & $-0,293$ \\
KURS & 0,015 & 0,012 & $-0,024$ & $-0,790$ & 0,164 & 1,000 & 0,942 & 0,710 \\
PDB & 0,018 & 0,013 & $-0,016$ & $-0,901$ & $-0,036$ & 0,942 & 1,000 & 0,843 \\
TA & 0,025 & 0,027 & $-0,001$ & $-0,986$ & $-0,293$ & 0,710 & 0,843 & 1,000 \\
\hline
\end{tabular}

Tabel 2. Hasil uji multikolinieritas akhir

\begin{tabular}{lcccccc}
\hline & CR & DER & TATO & BUNGA & KURS & TA \\
\hline CR & 1,000 & $-0,116$ & 0,020 & $-0,024$ & 0,015 & 0,025 \\
DER & $-0,116$ & 1,000 & $-0,075$ & 0,005 & 0,012 & 0,027 \\
TATO & 0,020 & $-0,075$ & 1,000 & $-0,024$ & $-0,024$ & $-0,001$ \\
BUNGA & $-0,024$ & 0,005 & $-0,024$ & 1,000 & 0,164 & $-0,293$ \\
KURS & 0,015 & 0,012 & $-0,024$ & 0,164 & 1,000 & 0,710 \\
TA & 0,025 & 0,027 & $-0,001$ & $-0,293$ & 0,710 & 1,000 \\
\hline
\end{tabular}

Tabel 3. Hasil uji chow dan hausman

\begin{tabular}{llll}
\hline Pengujian & Statistic & d.f & Prob. \\
\hline Uji Chow & 7,997 & $(268)$ & 0,000 \\
Uji Hausman & 0,000 & 6 & 1,000 \\
\hline
\end{tabular}


Hasil uji Chow menunjukkan nilai probabilitas dari fixed effect model kurang dari 0.05 sehingga fixed effect model dipilih sebagai model yang lebih baik dibandingkan common effect model. Tahap selanjutnya adalah memilih antara fixed effect model dan random effect model. Berdasarkan Tabel 3, hasil uji Hausman menunjukkan "Cross-section test variance is invalid" yang dilihat dari nilai prob sebesar 1.000 yang berarti pemilihan model tidak dapat dilakukan dengan uji Hausman. Oleh karenanya perlu digunakan alternatif dengan membandingkan nilai adjusted $R$-squared yang disajikan pada Tabel 4 (Jank, 2011). Jank (2011) menyatakan bahwa untuk mengevaluasi model regresi dapat menggunakan konsep $R$-squared. Tingginya nilai $R$-square menunjukkan bahwa model tersebut menjadi lebih lebih baik jika dibandingkan model yang lain. Sehingga untuk memperoleh model yang lebih baik dapat menggunakan perbandingan adusted $R$-squared. Model dengan nilai adjusted $R$-squared lebih besar dipilih sebagai model terbaik. Fixed effect model menghasilkan nilai adjusted $R$-squared lebih besar dibandingkan random effect model sehingga fixed effect model yang dipilih dalam penelitian ini.

\section{Uji Asumsi Klasik}

Uji asumsi klasik pada fixed effect model perlu dilakukan sebelum menganalisis hasil regresi data panel. Uji asumsi klasik tersebut meliputi uji normalitas, uji autokorelasi, dan uji heteroskedastisitas yang disajikan pada Tabel 5. Nilai probabilitas Jarque-Bera digunakan untuk melakukan uji normalitas. Berdasarkan Tabel 5, diketahui bahwa nilai probabilitasnya kurang dari 0,05 yang berarti residual tidak menyebar normal. Namun banyaknya data observasi yang digunakan dalam penelitian ini dapat memenuhi kriteria dalil limit pusat. Data observasi yang digunakan lebih dari 100 yaitu sebanyak 1614. Kriteria dalil limit pusat, yaitu semakin banyak data maka akan semakin mendekati normal dan membuat asumsi kenormalan dapat dipenuhi. Dengan demikian data observasi pada model dikatakan menyebar normal. Nilai Durbin-Watson digunakan untuk melakukan uji autokorelasi yaitu sebesar 1,623 (Tabel 5). Nilai tersebut mendekati angka 2 sehingga dapat disimpulkan bahwa tidak terdapat autokorelasi pada model. Uji heteroskedastisitas menggunakan nilai Sum Square Resid. Berdasarkan Tabel 5, nilai Sum Square Resid pada Weighted Statistics lebih kecil dari nilai Sum Square Resid pada Unweighted Statistics. Oleh karena itu, model terbebas dari masalah heteroskedastisitas.

\section{Hasil Regresi Fixed Effect Model}

Hasil regresi fixed effect model menghasilkan nilai koefisien determinasi ( $R$-squared) sebesar 0.657. Hal ini berarti variabel independen pada model yaitu TA, CR, DER, TATO, bunga, dan Kurs berpengaruh terhadap variabel NPM sebesar $65,7 \%$ dan sisanya sebesar $34,3 \%$ dipengaruhi oleh variabel lain diluar penelitian. Uji $\mathrm{F}$ menghasilkan nilai probabilitas (F-statistics) sebesar $0,000<0,01$ yang menunjukkan bahwa model layak pada taraf nyata $1 \%$. Hasil uji T disajikan pada Tabel 6. Hasil persamaan regresi data panel dari fixed effect model sebagai berikut:

$$
\begin{aligned}
\mathrm{NPM}_{\mathrm{it}}= & 2,85-0,016 * \mathrm{TA}_{\mathrm{it}}-0,012 * \mathrm{CR}_{\mathrm{it}}-0,005 * \mathrm{DER}_{\mathrm{it}} \\
& +\quad 0,009 * \mathrm{TATO}_{\mathrm{it}}+1,150 * \mathrm{BUNGA}_{\mathrm{it}}{ }^{-} \\
& 0,322 * \mathrm{KURS}_{\mathrm{it}}
\end{aligned}
$$

Tabel 4. Nilai Adjusted R-squared pada Model FEM dan REM

\begin{tabular}{lc}
\hline Model & Adjusted R-squared \\
\hline Fixed effect model (FEM) & 0,5871 \\
Random effect model (REM) & 0,0003 \\
\hline
\end{tabular}

Tabel 5. Hasil uji normalitas, autokorelasi, dan heteroskedastisitas

\begin{tabular}{lccc}
\hline Pengujian & Probability Jarque-Bera & Sum squared resid & Durbin-Watson stat \\
\hline Normalitas & 0,0000 & & \\
Heterokedastisitas & & & \\
a. Weighted Statistics & & 6973,92 & 1,623 \\
b. Unweighted Statistics & & 29628,36 & 1,819 \\
\hline
\end{tabular}


Tabel 6. Pengujian regresi data panel dengan model FEM

\begin{tabular}{lcccc}
\hline Variable & Coefficient & Std. Error & $t$-Statistic & Prob. \\
\hline C & 2,854 & 0,147 & 19,469 & 0,0000 \\
TA & $-0,016$ & 0,004 & $-4,401$ & $0,0000^{* * *}$ \\
CR & 0,012 & 0,002 & 5,587 & $0,0000^{* * *}$ \\
DER & $-0,005$ & 0,002 & $-2,917$ & $0,0036^{* * *}$ \\
TATO & 0,010 & 0,004 & 2,421 & $0,0156^{* * *}$ \\
BUNGA & 1,150 & 0,184 & 6,267 & $0,0000^{* * *}$ \\
KURS & $-0,322$ & 0,016 & $-19,894$ & $0,0000^{* * *}$ \\
\hline
\end{tabular}

*** significant at level $5 \%$

Nilai koefisien menunjukkan besaran pengaruh variabel independen terhadap variabel dependen. Koefisien negatif menunjukkan variabel berpengaruh negatif yang berarti setiap kenaikan variabel independen akan menurunkan variabel dependen. Sebaliknya, koefisien yang positif menunjukkan variabel berpengaruh positif yang berarti setiap kenaikan variabel independen akan meningkatkan variabel dependen. Berdasarkan Tabel 6, variabel TA dan DER berpengaruh negatif terhadap NPM, sedangkan variabel CR, TATO, dan Suku Bunga berpengaruh positif terhadap NPM. Berbeda dengan KURS, secara statistik kurs berpengaruh negatif namun nilai kurs yang meningkat berarti nilai tukar rupiah melemah (depresiasi) sehingga pembahasan nilai koefisien dari kurs akan dibalik yang membuat kurs menjadi berpengaruh positif terhadap NPM. Nilai probabilitas seluruh variabel kurang dari 0.05 yang menunjukkan bahwa variabel-variabel tersebut berpengaruh signifikan terhadap NPM.

\section{Tax Amnesy dan Profitablitas}

Hasil regresi menunjukkan bahwa tax amnesty berpengaruh negatif signifikan terhadap profitabilitas sehingga hipotesis $\left(\mathrm{H}_{1}\right)$ diterima. Hal ini mengindikasikan bahwa adanya tax amnesty justru menurunkan profitabilitas. Beberapa penelitian sebelumnya juga menyatakan hal serupa seperti penelitian Rinaldi (2017) dan Tiurmauli et al. (2018). Penurunan profitabilitas perusahaan yang mengikuti tax amnesty dapat disebabkan oleh beberapa alasan. Salah satunya adalah perusahaan yang mengikuti tax amnesty disamping melaporkan aset, dapat juga melaporkan kewajiban atau utang yang sebelumnya tidak dilaporkan dalam laporan keuangan. Tiurmauli et al. (2018) menyebutkan bahwa penurunan profitabilitas perusahaan dapat terjadi karena adanya pengeluaran dana tunai perusahaan berupa utang dan pembayaran bunga yang jauh lebih besar setelah mengikuti tax amnesty. Penambahan aset belum tentu akan menghasilkan pendapatan bagi perusahaan, bahkan aset tersebut juga akan menimbulkan biaya seperti biaya penyusutan, biaya pemeliharaan dan biaya operasional lainnya. Munculnya biaya ini merupakan konsekuensi dari dilaporkannya aset tersebut dalam Surat Pernyataan Pengampunan Pajak. Jika sebuah aset tidak dilaporkan maka lazimnya biaya atas aset tersebut juga tidak dilaporkan. Begitu juga sebaliknya, pada saat aset tersebut dilaporkan maka biaya atas aset tersebut juga akan dilaporkan. Sehingga akan menurunkan laba dari perusahaan.

\section{Likuiditas dan Profitabilitas}

Current ratio (likuiditas) berpengaruh positif signifikan terhadap profitabilitas sehingga hipotesis $\left(\mathrm{H}_{2}\right)$ ditolak. Hal ini berarti peningkatan likuiditas akan mampu meningkatkan profitabilitas perusahaan. Hasil ini didukung oleh beberapa penelitian sebelumnya yaitu Mahaputra (2012) dan Meidiyustiani (2016). Likuiditas yang optimal mengindikasikan perusahaan mampu membayar utang jangka pendeknya. Hal ini akan menarik minat investor untuk berinverstasi (Mahaputra, 2012). Adanya penambahan dana investasi akan dimanfaatkan oleh perusahaan sebagai modal untuk meningkatkan laba (Meidiyustiani, 2016). Ada juga risiko yang dapat timbul apabila likuiditas terlalu tinggi. Menurut Zygmunt (2013) dan Al-Jafari dan Alchami (2014) likuiditas yang terlalu tinggi dapat menurunkan profitabilitas.

\section{Leverage dan Profitabilitas}

Debt to equity ratio (leverage) berpengaruh negatif signifikan terhadap profitabilitas sehingga hipotesis $\left(\mathrm{H}_{3}\right)$ diterima. Hal ini mengindikasikan bahwa peningkatan leverage justru akan menurunkan profitabilitas perusahaan. Penggunaan hutang yang lebih besar 
daripada ekuitas akan mengurangi profitabilitas (Rizki et al. 2019). Rasio utang yang tinggi menandakan penggunaan utang yang besar dan semakin besarnya ketergantungan perusahaan pada pihak luar (Hantono, 2015) sehingga akan meningkatkan risiko keuangan pada perusahaan. Ketika debt to equity ratio meningkat sedangkan aset yang dimiliki tetap sama akan berakibat pada penurunan laba perusahaan (Silitonga et al. 2017). Hal ini disebabkan oleh adanya kenaikan biaya utang sehingga berakibat pada menurunnya profitabilitas perusahaan. Terbitnya Peraturan Menteri Keuangan nomor 169/PMK.010/2015 tanggal 09 September 2015, yang mengatur besaran perbandingan antara utang dan modal ditetapkan paling tinggi sebesar empat dibanding satu (4: 1) dalam keperluan perhitungan Pajak Penghasilan (PPh), menyebabkan tidak seluruh biaya atas utang dapat dibiayakan, sehingga biaya pajak menjadi lebih tinggi.

\section{Efisiensi dan Profitabilitas}

Rasio total assets turnover (efisiensi) berpengaruh positif signifikan terhadap profitabilitas sehingga hipotesis $\left(\mathrm{H}_{4}\right)$ diterima. Ketika efisiensi perusahaan meningkat maka profitabilitasnya juga akan meningkat. Hasil ini sejalan dengan hasil penelitian Barus \& Leliani (2013) dan Saleh dan Mohammed (2018). Rasio total asset turnover menggambarkan tingkat efisiensi perusahaan dalam mengelola sumberdaya yang dimiliki. Semakin efisien perusahaan dalam mengelola sumberdayanya semakin tinggi pula laba yang dapat dihasilkan. Sebaliknya, ketika pengelolaan sumberdaya perusahaan tidak efisien maka akan meningkatkan beban perusahaan yang berimbas pada penurunan pendapatan dan laba (Barus dan Leliani, 2013).

\section{Tingkat Suku Bunga dan Profitabilitas}

Tingkat suku bunga berpengaruh positif signifikan terhadap profitabilitas sehingga hipotesis $\left(\mathrm{H}_{7}\right)$ ditolak. Hal ini berarti peningkatan suku bunga akan meningkatkan profitabilitas perusahaan dan sebaliknya, penurunan suku bunga akan menurunkan profitabilitas. Hasil ini didukung oleh hasil penelitian Claessens et al. (2017). Pada perusahaan perbankan, ketika tingkat suku bunga meningkat dan disesuaikan dengan tingkat suku bunga kredit maka pendapatan perusahaan juga akan meningkat. Namun, ketika bank terlambat untuk menyesuaikan suku bunga maka biaya bank lebih cepat meningkat daripada pendapatan yang berakibat pada penurunan profitabilitas bank (Sufian, 2011). Ketika suku bunga meningkat maka beban biaya perusahaan juga meningkat sehingga harga produk yang ditawarkan perusahaan juga meningkat. Pada perusahaan nonperbankan, dengan naiknya tingkat suku bunga maka harga-harga akan ikut naik. Jika perusahaan tersebut dapat mempertahankan atau menekan persentase biaya variabel sehingga perusahaan menjadi lebih efisien maka perusahaan akan memperoleh peningkatan laba. Apabila terjadi peningkatan suku bunga namun perusahaan mampu menerima laba yang lebih tinggi maka profitabilitas perusahaan juga akan meningkat (Aditya dan Badjra, 2018).

\section{Kurs dan Profitabilitas}

Nilai koefisien kurs sebesar $-0,3221$ menunjukkan bahwa secara statistik variabel kurs berhubungan negatif dengan NPM. Hal ini berarti setiap peningkatan kurs sebesar 100\% (kurs melemah) akan menurunkan NPM sebesar 32,21\%. Nilai kurs yang meningkat berarti nilai tukar rupiah melemah (depresiasi) sehingga akan menurunkan NPM dan sebaliknya nilai kurs yang menurun atau menguat (apresiasi) akan meningkatkan NPM. Berdasarkan hal tersebut apresiasi atau depresisasi kurs berpengaruh positif signifikan terhadap NPM sehingga hipotesis (H8) diterima. Untuk itu hasil persamaan yang negatif dibalik karena pembahasannya juga terbalik. Kewal (2012) menyatakan bahwa perubahan kurs rupiah memengaruhi pendapatan dan biaya operasional perusahaan. Kurs yang terapresiasi akan meningkatkan profitabilitas (Zhang dan Ouyang, 2018). Sebaliknya, kurs yang terdepresiasi akan menurunkan profitabilitas (Ulfa et al. 2016). Adanya apresiasi kurs akan membuat perusahaan mengurangi biaya input impor untuk lebih berorientasi memasarkan produknya di dalam negeri, sehingga biaya operasional perusahaan dapat dikurangi dan dapat dioptimalkan untuk meningkatkan pendapatan. Ketika kurs melemah, biaya yang dikeluarkan perusahaan akan semakin meningkat untuk menanggung beban operasionalnya sehingga akan menekan pendapatan perusahaan (Riantani dan Tambunan, 2013). Swandayani dan Kusumaningtias (2012) menyatakan bahwa mata uang yang menurun secara signifikan akan menurunkan daya beli dari jenis investasi apapun. Penurunan investasi tersebut akan berdampak pada kegiatan operasional perusahaan yang memengaruhi penurunan pendapatan dan laba. 


\section{Implikasi Manajerial}

Direktorat Jenderal Pajak dapat melihat bahwa tax amnesty bagi perusahaan publik berpengaruh negatif (menurun) terhadap profitabilitas. Jika tax amnesty tersebut ditujukan untuk untuk meningkatkan pendapatan pajak di masa mendatang Yustiari (2016), Direktorat Jenderal Pajak perlu mengkaji lebih dalam apabila ingin kembali menerbitkan tax amnesty. Hal ini karena net profit margin emiten peserta tax amnesty yang menurun menunjukkan bahwa tax ratio dari emiten justru makin turun. Jika tujuan tax amnesty adalah untuk mendapatkan penerimaan pajak secara cepat dari uang tebusan, Direktorat Jenderal Pajak cukup menerbitkan kebijakan-kebijakan sebelum tax amnesty seperti kebijakan Sunset Policy atau Peraturan Kementerian Keuangan Nomor 91/PMK.03/2015 tentang Pengurangan atau Penghapusan Sanksi Administrasi. Hasil penelitian ini juga menunjukkan bahwa masih terdapat emiten yang tidak melaksanakan prinsip-prinsip GCG sehingga OJK (Otoritas Jasa Keuangan) harus meningkatkan pengasawan terhadap pelaksanaan GCG emiten. OJK juga perlu mempertimbangkan ada atau tidaknya kesalahan mengenai laporan aset pengampunan pajak yang memiliki nilai relatif besar sebagaimana yang dimaksud dalam Pernyataan Standar Akutansi Keuangan (PSAK) 25. Jika ada maka perlu dilakukan penyajian kembali (restatement) laporan keuangan. Selain itu, perlu dilakukan pengawasan terhadap auditor emiten-emiten untuk mengetahui keabsahannya dalam mendeteksi aset tax amnesty.

Adanya tax amnesty menunjukkan bahwa masih terdapat ketidakterbukaan informasi pada pasar Indonesia, sehingga meningkatkan risiko investasi di Indonesia. Jika program tax amnesty kembali diadakan, calon investor akan mengetahui bahwa kinerja perusahaan akan memburuk. Berdasarkan hal tersebut, investor disarankan untuk tidak melakukan investasi ke pasar saham Indonesia selama kebijakan tax amnesty dilaksanakan. Sisi positif dari program tax amnesty adalah adanya tax amnesty akan menyebabkan pertambahan aset yang sebelumnya tidak diungkapkan dalam laporan keuangan. Investor tentunya dapat memilih antara pertambahan aset tersebut atau penurunan kinerja selama pemberlakuan tax amnesty. Penurunan profitabilitas akibat mengikuti tax amnesty juga dapat menjadi pertimbangan bagi manajemen perusahaan. Jika ada kebijakan tax amnesty berikutnya, manajemen sudah dapat mengambil langkah-langkah untuk mengantisipasi kemungkinan penurunan kinerja.

\section{KESIMPULAN DAN SARAN}

\section{Kesimpulan}

Hasil menunjukkan bahwa tax amnesty berpengaruh negatif signifikan terhadap profitabilitas. Hal ini berarti diberlakukannya kebijakan tax amnesty justru menurunkan profitabilitas perusahaan. Leverage juga berpengaruh negatif signifikan terhadap profitabilitas. Penggunaan utang yang besar akan meningkatkan risiko keuangan pada perusahaan. Likuiditas berpengaruh positif signifikan terhadap profitabilitas. Likuiditas yang optimum akan meningkatkan kemampuan perusahaan dalam menghasilkan laba, namun likuiditas yang terlalu tinggi justru akan menurunkan laba. Efisiensi berpengaruh positif signifikan terhadap profitabilitas. Semakin efisien perusahaan dalam mengelola sumberdayanya, semakin tinggi pula laba yang dapat dihasilkan. Tingkat suku bunga dan kurs berpengaruh positif signifikan terhadap profitabilitas. Apresiasi kurs dapat meningkatkan profitabilitas dan sebaliknya, depresiasi kurs dapat menurunkan profitabilitas perusahaan.

\section{Saran}

Hasil penelitian menunjukkan bahwa masih terdapat emiten yang tidak melaksanakan prinsip-prinsip Good Corporate Governance (GCG) sehingga Otoritas Jasa Keuangan harus meningkatkan pengawasan terhadap pelaksanaan GCG emiten. Meningkatnya transparansi emiten, akan meningkatkan tingkat keterbukaan informasi pasar modal Indonesia sehingga tingkat efisiensi pasar modal Indonesia juga meningkat. Di samping itu, tingkat kepercayaan investor akan menjadi lebih baik terhadap informasi laporan keuangan yang disajikan oleh emiten. Keterbatasan penelitian ini adalah jangka waktu penelitian terbatas pada 3 tahun sebelum dan setelah tax amnesty. Penelitian selanjutnya dapat mengidentifikasi alasan perusahaan yang mengikuti tax amnesty, dampak tax amnesty terhadap profitabilitas pada emiten selain yang terdapat di papan utama Bursa Efek Indonesia, dan dampak tax amnesty terhadap profitabilitas di private company.

\section{DAFTAR PUSTAKA}

Aditya IGNW, Badjra IB. 2018. Peran profitabilitas dalam memediasi pengaruh tingkat suku bunga dan leverage terhadap return saham. E-Jurnal 
Manajemen Unud 7(4):1831-1861.

Al-Jafari MK, Alchami M. 2014. Determinants of bank profitability: Evidence from Syria. Journal of Applied Finance \& Banking 4(1):17-45.

Allen AJ, Shaik S, Myles AE, Yeboah O-A. 2011. Determinants of profitability performance: An analysis of class I railroads in the United States. Di dalam: The Southern Agricutural Economics Assosiation (SAEA) Annual Meeting. Corpus Christi: Ageconsearch. hlm. 1-18.

Andes SL, Puspitaningtyas Z, Prakoso A. 2017. Pengaruh inflasi, kurs rupiah dan suku bunga terhadap return saham perusahaan manufaktur. Jurnal Akuntansi Keuangan dan Bisnis 10(2):816.

Ariani R, Afifudin, Mawardi MC. 2018. Analisis perbandingan kinerja keuangan sebelum dan sesudah diberlakukannya tax amnesty periode ketiga tahun 2016 pada perusahaan sub sektor tekstil dan garmen yang terdaftar di BEI. E-Jra. 7(9):65-76.

Ariefianto M. 2012. Ekonometrika: Esensi dan aplikasi dengan menggunakan EVIEWS. Jakarta: Erlangga.

Athanasoglou PP, Brissimis SN, Delis MD. 2008. Bankspesific, industry-spesific and macroeconomic determinants of bank profitability. Journal of International Financial Markets, Institutions and Money 18(2):121-136.

Barus AC, Leliani. 2013. Analisis faktor-faktor yang memengaruhi profitabilitas pada perusahaan manufaktur yang terdaftar di Bursa Efek Indonesia. Jurnal Wira Ekonomi Mikroskil 3(2):111-121.

De Carvalho PG, Serrasqueiro Z, Nunes PM. 2013. Profitability determinants of fitness SMEs: Empirical evidence from Portugal using panel data. Amfiteatru Economic 15(34):417-430.

Claessens S, Coleman N, Donnelly M. 2017. "Low-ForLong" interest rates and banks' interest margins and profitability: Cross-country evidence. Journal Finance Intermediation 35:1-16. https:// doi.org/10.1016/j.jfi.2017.05.004.

Elsiefy E. 2013. Determinants of profitability of commercial banks in Qatar: Comparative overview between domestic conventional and Islamic banks during the period 20062011. International Journal of Economic and Management Sciences 2(11):108-142.

Hantono. 2015. Pengaruh currentratio dan debt To equity ratio terhadap profitabilitas pada perusahaan manufaktur sektor logam dan sejenisnya yang terdaftar di Bursa Efek Indonesia periode 20092013. Jurnal Wira Ekonomi Mikroskil 5(1):2130.

Harahap SS. 2011. Teori Akuntansi. Revisi 201. Jakarta: Rajawali Press.

Jank W. 2011. Business Analytics for Managers. Gentleman R, Hornik K, Parmigiani G, editor. New York: Springer.

Kalengkongan G. 2013. Tingkat suku bunga dan inflasi pengaruhnya terhadap return on asset (ROA) pada industri perbankan yang go public di Bursa Efek Indonesia. Jurnal Riset Ekonomi, Manajemen, Bisnis dan Akuntansi 1(4):737-747.

Karim A. 2015. Analisis pengaruh faktor internal dan eksternal terhadap return saham perusahaan manufaktur yang terdaftar di Bursa Efek Indonesia (BEI) periode 2010-2012. Media Ekonomi dan Manajemen 30(1):41-55.

Kewal SS. 2012. Pengaruh inflasi, suku bunga, kurs, dan pertumbuhan PDB terhadap indeks harga saham gabungan. Jurnal Economia 8(1):53-64.

Lee C-Y. 2014. The effects of firm specific factors and macroeconomics on profitability of propertyliability insurance industry in Taiwan. Asian Economic and Financial Review 4(5):681-691.

Mahaputra INKA. 2012. Pengaruh rasio-rasio keuangan terhadap pertumbuhan laba pada perusahaan manufaktur yang terdaftar di BEI. Jurnal Akuntansi \& Bisnis 7(2):243-254.

Meidiyustiani R. 2016. Pengaruh modal kerja, ukuran perusahaan, pertumbuhan penjualan dan likuiditas terhadap profitabilitas pada perusahaan manufaktur sektor industri barang konsumsi yang terdaftar di Bursa Efek Indonesia (BEI) periode tahun 2010-2014. Jurnal Akuntansi dan Keuangan 5(2):41-59.

Munawir S. 2004. Analisis Rasio Keuangan. Yogyakarta: Liberti.

Pervan M, Mlikota M. 2013. What determines the profitability of companies: Case of Croatian food and beverage industry. Econoic ResearchEkonomska Istraživanja 26(1):277-286. https:// doi.org/10.1080/1331677X.2013.11517602.

Ramadanti F, Meiranto W. 2015. Analisis pengaruh risikolikuiditasterhadap profitabilitas perusahaan perbankan di Indonesia. Diponegoro Journal of Accounting 4(2):447-456.

Rehman MZ, Khan MN, Khokhar I. 2014. Select financial ratios as a determinant of profitability evidence from petrochemical industry in Saudi 
Arabia. European Journal. Business and Management 6(6):187-196.

Riantani S, Tambunan M. 2013. Analisis pengaruh variabel makroekonomi dan indeks global terhadap return saham. Semantik 3(1):532-357.

Rinaldi. 2017. Dampak tax amnesty terhadap laporan keuangan dan pengaruhnya kepada nilai perusahaan.JurnalPenelitiandanPengembangan Ilmu Administrasi dan Humaniora 7(1):33-43.

Rizki A, Anggraeni L, Hardiyanto AT. 2019. Significant Impact of Working Capital and Macroeconomic Condition on Profitability in Property Industry. Jurnal Aplikasi Bisnis dan Manajemen 5(1):121130. https://doi.org/10.17358/jabm.5.1.121.

Sahara AY. 2013. Analisis pengaruh inflasi, suku bunga $\mathrm{BI}$, dan produk domestik bruto terhadap return on asset (ROA) bank syariah di Indonesia. Jurnal Ilmu Manajemen 1(1):149-157.

Saleh AA, Mohammed AS. 2018. Factors affecting profitability in Malaysia. Journal of Economic Studies 45(3):442-458. https://doi.org/10.1108/ JES-05-2017-0124.

Santoso AB. 2018. Tutorial \& Solusi Pengolahan Data Regresi. Agung Budi Santoso.

Saraçoğlu OF, Çaşkurlu E. 2011. Tax amnesty with effects and effecting aspects: Tax compliance, tax audits and enforcements around the Turkish case. International Journal of Business and Social Science 2(7):95-103. https://doi.org/10.30845/ ijbss.

Silitonga HP, Siregar L, Tarigan P, Inrawan A. 2017. Pengaruh likuiditas dan leverage terhadap profitabilitas pada PT Japfa Comfeed Indonesia, Tbk yang terdaftar di Bursa Efek Indonesia. Jurnal Financial 3(1):1-9.

Sufian F. 2011. Profitability of the Korean Banking sector: Panel evidence on banking-specific and macroeconomic determinats. Journal of Economics and Management 7(1):43-72.

Sumantyo R, Savitri DA. 2019. Macroeconomic variables towards net asset value of sharia mutual funds in Indonesia and Malaysia. Jurnal Keuangan dan Perbankan 23(2):300-307. https://doi.org/10.26905/jkdp.v23i2.2195.

Swandayani DM, Kusumaningtias R. 2012. Pengaruh inflasi, suku bunga, nilai tukar valas dan jumlah uang beredar terhadap profitabilitas pada Perbankan Syariah di Indonesia periode 20052009. Akrual 3(2):147-166.

Tiurmauli K, Pasu R, Fauziah F, Halawa SD, Rahayu CA. 2018. The Impact of Tax Amnesty Policy Influence the Investment Decision and Profitability in Stock Prices The Best 45 Companies in Indonesia. Di dalam: IOP Conference Series: Earth and Environmental Science. Vol. 175. Makassar: IOP Publishing Ltd. hlm. 1-6.

Ulfa M, Puspitaningtyas Z, Bidhari SC. 2016. Pengaruh fluktuasi nilai tukar mata uang Rupiah-Dolar terhadap profitabilitas perusahaan manufaktur yang terdaftar di BEI periode 2010-2014. Jurnal Ekonomi \& Bisnis 10(2):131-142.

Ulzanah AA, Murtaqi I. 2015. The impact of earnings per share, debt to equity ratio, and current ratio towards the profitability of companies listed in LQ45 From 2009 to 2013. Journal of Business and Management 4(1):18-27.

Vireyto N, Sulasmiyati S. 2017. Analisis pengaruh return on asset, return on equity, dan earning per share terhadap harga saham (Studi pada perusahaan Bank BUMN yang listed di Bursa Efek Indonesia periode 2006-2016). Jurnal Administrasi Bisnis 51(1):75-82.

Yuksel S, Zengin S. 2017. Influencing factors of net interest margin in Turkish banking sector. Intetnationsl Journal of Economics and Financial Issues 7(1):178-191.

Yustiari SH. 2016. Tax Amnesty dalam Perspektif Good Governance. Jurnal Ilmu Administrasi Publik 2(4):169-174.

Zhang T, Ouyang P. 2018. Is RMB appreciation a nightmare for the Chinese firms? An analysis on firm profitability and exchange rate. International Review of Economics \& Finance 54:27-43. https://doi.org/10.1016/j.iref.2017.05.003.

Zygmunt J.2013. Does liquidity impact on profitability? Conference Informatics and Management Sciences 247-251. 